\title{
Nesting ecology and the cultural importance of stingless bees to speakers of Yoloxóchitl Mixtec, an endangered language in Guerrero, Mexico
}

\author{
Victor H. Gonzalez ${ }^{1}$, Jonathan D. Amith ${ }^{2,3}$, Timothy J. Stein ${ }^{4}$ \\ ${ }^{1}$ Undergraduate Biology Program and Department of Ecology and Evolutionary Biology, University of Kansas, Haworth \\ Hall, 1200 Sunnyside Ave, Lawrence, KS 66045, USA \\ ${ }^{2}$ Department of Anthropology, Gettysburg College, 300 North Washington St., Campus Box 2985, Gettysburg, PA \\ 17325 , USA \\ ${ }^{3}$ Department of Anthropology, National Museum of Natural History, Smithsonian Institution, 10th St. \& Constitution \\ Ave. NW, Washington, DC 20004, USA \\ ${ }^{4}$ Physician Associate Program, Department of Family \& Preventive Medicine, College of Medicine, University of \\ Oklahoma, 940 Stanton L. Young Blvd., Suite 357, Oklahoma City, OK 73104, USA
}

Received 6 January 2018 - Revised 3 May 2018 - Accepted 31 May 2018

\begin{abstract}
Stingless bees (Apidae: Meliponini) are major pollinators of many wild and cultivated plants, and both indigenous and non-indigenous populations use their products for diverse purposes including food, crafts, and medicine. However, many aspects of both stingless bee nesting ecology and traditional knowledge of these culturally significant bees by diverse human populations remain unknown or poorly documented. We report on the nest architecture, nesting substrate, host plants, and local abundance of stingless bees occurring in Yoloxóchitl, one of several indigenous villages that speak Yoloxóchitl Mixtec, an endangered language on the Pacific Coast of the state of Guerrero. We also document local Indigenous nomenclature, classification, and use of these bees as well as traditional management practices and knowledge of their behavior. Lastly, we offer a preliminary quantitative analysis of the relative cultural importance of each bee species and explore the relationship of traditional ecological knowledge to these species.
\end{abstract}

conservation / cultural importance index / ethnomelittology / meliponiculture / nest architecture

\section{INTRODUCTION}

Worldwide, bees are the most important pollinators and their value to science and society is undeniable. They play a crucial role in ecosystem health and plant reproduction and, as a consequence, in general food security. Among arthropods, they are notable for high social and cultural

Electronic supplementary material The online version of this article (https://doi.org/10.1007/s13592-018-0590-2) contains supplementary material, which is available to authorized users.

Corresponding author: V. Gonzalez, victorgonzab@gmail.com

Manuscript editor: Alexandra Klein values (Berenbaum et al. 2006; Klein et al. 2007; Gonzalez et al. 2013; Potts et al. 2016). Recent worldwide decline of bee populations and species diversity has raised global environmental and economic concerns, as pollinator loss will negatively affect global human diet and health and crop market economies, as well as the livelihood of farmers and beekeepers (e.g., Biesmeijer et al. 2006; Berenbaum et al. 2006; Potts et al. 2010, 2016).

Stingless bees (Meliponini) are social bees restricted to the tropical and subtropical areas of the world and the vast majority $(\sim 80 \%)$ are in the Western Hemisphere, from Mexico to Brazil and northern Argentina (Michener 2007; Camargo and Pedro 2007). Although stingless bees represent a 
very small fraction $(2.5 \%)$ of the more than 20,000 known bee species worldwide, they are among the most ecologically, economically, and culturally significant bees in tropical and subtropical areas. They are major pollinators of many native, introduced, and cultivated plants, and some species are managed to promote pollination of diverse crops (Slaa et al. 2006). Indigenous and non-Indigenous populations in many regions of the world use the honey, pollen, cerumen, and propolis of numerous species for diverse purposes, including food, medicine, and crafts. In some cases, these bee products represent unique or additional sources of income or alternative medicines (e.g., Stearman et al. 2008; Ayala et al. 2013; Villanueva-Gutiérrez et al. 2013; Carvalho et al. 2014; Vit et al. 2015; Zamudio and Alvarez 2016). Mayans and Aztecs used stingless bees in preColumbian times and that tradition endures in many areas of present-day Mexico (e.g., Ayala et al. 2013; Villanueva-Gutiérrez et al. 2013).

Despite the importance of stingless bees and the numerous accounts on their nesting biology (e.g., Schwarz 1948; Wille and Michener 1973), many basic aspects (e.g., nest architecture) remain unknown or poorly documented for the majority of the species, thus hindering our understanding of their evolution, ecology, and diversity (Roubik 2006). Several of these nesting features are also useful in species recognition, as numerous species of stingless bees are very similar morphologically and can only be distinguished by morphological features of the male, which is rarely collected, and differences in nest architecture or nesting substrate (Camargo and Pedro 2003a, b; Michener 2007).

Similarly, Indigenous and local knowledge on stingless bees is still poorly documented and understood. Such knowledge is an invaluable component of our cultural capital, but it is rapidly disappearing under the impact of globalization. It may not only inform us of alternative conservation practices to enhance health, abundance, and diversity of pollinators (Posey 1983, 1993; Posey and Camargo 1985; Stearman et al. 2008; Ayala et al. 2013; IPBES 2016), but also might prove useful in the recognition of new species (e.g., Portugal-Araújo and Kerr 1959; Michener 1959).

Herein, we document the nest architecture, nesting substrate, and local abundance of six species of stingless bees from Yoloxóchitl. We also report on Indigenous knowledge of their behavior, uses, management practices, nomenclature, and classification by speakers of Yoloxóchitl Mixtec, a rapidly disappearing language currently spoken by only about 5000 people (Castillo 2007; DiCanio et al. 2015). Based on biological and ethnographic information, we quantitatively assess the relative cultural importance of each bee species and explore its relationship with their local abundance.

\section{MATERIALS AND METHODS}

\subsection{Study area and bee surveys}

We conducted bee surveys during the middle of the dry season (2-12 January 2014) in the following vegetation types found within a $5.0-\mathrm{km}$ radius of the village of Yoloxóchitl (16.81650,98.68605; 500-830 m): (1) tropical dry forest remnants; (2) oak forest; (3) cropland planted with corn, beans, squash, and sugarcane; and (4) grazing pastures with scattered trees and shrubs. Yoloxóchitl has a population of about 3500 and is located $5 \mathrm{~km}$ east of San Luis Acatlán, the municipal capital, in the state of Guerrero, Mexico (Fig. S1).

We collected bees from flowers and nests using aerial nets. We euthanized bees with acetone and preserved them in ethanol (95\%). For each nest, we recorded the geographic coordinates, altitude, type of vegetation, and the following nest-specific details: height above ground, length and diameter of nest entrance, type of nesting substrate (wood, ground, etc.), type of nest (aerial, semi-exposed, etc.), and defensive behavior when an observer approached the nest entrance. We were able to document the internal architecture of the nests of Partamona bilineata (Say) and Plebeia moureana Ayala. We opened nests with pocketknives, axes, and chisels, and measured internal features with a caliper. Mean values are provided with ranges and standard deviations.

\subsection{Traditional knowledge and uses}

To document local knowledge, including names and uses of bees and their products, we conducted open and semi-structured interviews 
with two local experts from Yoloxóchitl, men 30 and 55 years of age and fluent in both Yoloxóchitl Mixtec and Spanish. We gathered information while using the "walk-in-the-woods" method (Phillips and Gentry 1993a), in which consultants actively led the collecting trips in search of the bees they know and use. Whenever we collected a specimen at a flower or found a nest, we asked the consultants if they recognized the bee, had a name for it, or used it or its products. We also asked the meaning of the bee's name, the criteria by which they identified the bee, as well as how and how often they use it. During the interviews, we recorded this information in a notebook as well as in an Olympus ${ }^{\circledR}$ digital voice recorder WS-210S. Names in Yoloxóchitl Mixtec follow the practical orthography used by Amith and Castillo (unpubl. data), with superscript numbers indicating tone (level tones range from 1 low to 4 high, with additional rising, falling, and contour tones). Apostrophes indicating vowel laryngealization, which is often realized as a glottal stop. Final/n/ indicates a nasal vowel.

\subsection{Data analysis and voucher specimens}

We employed a uses totaled or researcher tally method (Phillips 1996) to determine the relative cultural importance (RCI) of each bee species. We grouped all mentioned uses (nine total) in four categories (food, medicine, materials for handcrafts, and other) and calculated the relative importance for each bee species based on the sum of the normalized number of use categories (\#C) and the normalized number of specific uses $(\# U)$. Then, we multiplied the resulting value by 50 to express it in a scale of 100. For example, Frieseomelitta nigra (Cresson) is used in one of the four categories, and thus it has a normalized $\mathrm{C}$ of $1 / 4=0.25$. Because only one specific use is recorded for F. nigra out of the nine reported for Scaptotrigona hellwegeri (Friese), the most versatile species, it has a normalized $U$ of $1 / 9=0.11$. Therefore, F. nigra has a RCI of $18([0.25+0.11] \times 50)$. This index is a modification of that developed by Bennett and Prance (2000) to calculate the relative importance of medicinal plants and is the most appropriate for our data considering the number of local consultants that participated in the study and duration of the fieldwork (for a discussion see, Hoffman and Gallaher 2007). We used a Chisquare Goodness-of-fit test to compare the number of diagnostic features used by informants among ethnospecies and a Spearman's rank correlation to test for association between the percentage of nests recorded during the surveys and the calculated RCI.

Voucher specimens and nest structures are in the insect collection of the Estación de Biología Chamela, Universidad Nacional Autónoma de Mexico, and Snow Entomological Collection, Division of Entomology, University of Kansas Natural History Museum, Lawrence, Kansas, USA.

\section{RESULTS}

\subsection{Nesting biology}

During the survey, we identified eight species of stingless bees and found 32 nests from a total of six species (Table I). We collected only two specimens of Trigonisca azteca Ayala while they were attracted to body sweat during our survey; in 2010 one of the consultants collected the only five specimens of the cleptobiotic bee Lestrimelitta chamelensis Ayala available to us. Nests of Nannotrigona perilampoides (Cresson) were the most common. We found them in all types of vegetation surveyed and consistently inside tree cavities of living Quercus peduncularis Neé (Fagaceae), Enterolobium cyclocarpum (Jacq.) Griseb. (Fabaceae), and Ficus spp. (Moraceae). We occasionally found two or three nests in the same tree trunk. The nest entrance consisted of a soft, light-to-dark brown wax tube of variable length.

We found all nests of $S$. hellwegeri in tropical dry forest and oak forest remnants. Nests were built inside cavities of living trees of Q. peduncularis, Ficus sp., Persea americana Mill. (Lauraceae), Cecropia obtusifolia Bertol. (Urticaceae), Bursera simaruba (L.) Sarg. (Burseraceae), and Byrsonima crassifolia (L.) Kunth (Malpighiaceae). Two of the six nests had two nest entrances. In all cases, the nest entrance was located in a crevice of the trunk, lined with dark wax, and guarded by numerous workers. 
Table I. Number of nests and information on some nesting features for each species of stingless bees found in Yoloxóchitl, Guerrero, Mexico. When available, ranges are followed, in parentheses, by mean value and standard deviation. —, not applicable.

\begin{tabular}{|c|c|c|c|c|c|c|}
\hline Bee species & $\begin{array}{l}\text { No. of } \\
\text { nests (\%) }\end{array}$ & Height (m) & $\begin{array}{l}\text { Trunk } \\
\text { diameter }(\mathrm{m})\end{array}$ & $\begin{array}{l}\text { Entrance } \\
\text { length }(\mathrm{cm})\end{array}$ & $\begin{array}{l}\text { Entrance } \\
\text { diameter }(\mathrm{cm})\end{array}$ & Substrate \\
\hline $\begin{array}{l}\text { Frieseomelitta nigra } \\
\text { (Cresson) }\end{array}$ & $3(9.4)$ & $\begin{array}{l}0.2-1.0(0.6 \pm \\
0.57, n=3)\end{array}$ & $0.2-0.4$ & 1.8 & $0.8-0.9$ & Dead trees \\
\hline $\begin{array}{l}\text { Lestrimelitta } \\
\text { chamelensis Ayala }\end{array}$ & 0 & - & - & - & - & - \\
\hline $\begin{array}{l}\text { Nannotrigona } \\
\text { perilampoides } \\
\text { (Cresson) }\end{array}$ & 15 (46.9) & $\begin{array}{l}0.2-3.0(1.19 \\
\pm 1.02, n=8)\end{array}$ & $\begin{array}{l}0.2-0.8(0.53 \\
\pm 0.31, n=9)\end{array}$ & $\begin{array}{l}1.5-15.0(5.1 \\
\pm 5.65, n=8)\end{array}$ & $\begin{array}{c}0.8-1.7(1.12 \\
\pm 0.29, n=9)\end{array}$ & Living trees \\
\hline $\begin{array}{l}\text { Partamona } \\
\text { bilineata (Say) }\end{array}$ & $6(18.8)$ & $>30$ & - & - & $2.5 \times 2.0$ & Living trees \\
\hline $\begin{array}{l}\text { Plebeia moureana } \\
\text { Ayala }\end{array}$ & $1(3.1)$ & 0.8 & 0.8 & 1.0 & 0.3 & Living trees \\
\hline $\begin{array}{l}\text { Scaptotrigona } \\
\text { hellwegeri (Friese) }\end{array}$ & $6(18.8)$ & $\begin{array}{r}0.6-5.0(2.53 \\
\pm 1.98, n=6)\end{array}$ & $\begin{array}{c}0.3-0.6(0.48 \\
\pm 0.15, n=6)\end{array}$ & - & - & Living trees \\
\hline $\begin{array}{l}\text { Trigona fulviventris } \\
\text { Guérin-Méneville }\end{array}$ & $1(3.1)$ & 0 & - & 2.5 & 2.2 & Ground \\
\hline $\begin{array}{l}\text { Trigonisca azteca } \\
\text { Ayala }\end{array}$ & 0 & - & - & - & - & - \\
\hline
\end{tabular}

The single nest of Trigona fulviventris GuérinMéneville was in the ground, at the base of a tree (Ficus sp.) located in the middle of a grazing pasture. The entrance was hidden by dried leaves and consisted of a hard tube with its lower portion elongated, thus forming a landing platform.

We found all nests of F. nigra in grazing pastures inside dried, dead trunks of Lysiloma sp. (Leguminosae). One was in a fence post. The entrance consisted of a narrow tube made of dark wax and was guarded by one or two workers.

All nests of $P$. bilineata were aerial nests (Fig. 1) built among the tallest branches of trees of Mangifera indica L. (Anacardiaceae), P. americana, Annona spp. (Annonaceae), and Inga megacarpa M.E. Jones (Fabaceae). We were able to dissect one nest, which was oval, about $16 \mathrm{~cm}$ in width and $33 \mathrm{~cm}$ in length. It was horizontally oriented with the entrance in its narrowest end. The nest entrance was funnelshaped, with dark, sticky resin droplets on its inner walls (Figs. 2 and 3). It continued into a vestibule that communicated with the brood chamber through an oval opening $(9.4 \mathrm{~mm} \times$ $5.5 \mathrm{~mm}$ ). The batumen consisted of dark brown to black brittle layers. It was about 2.0 to $3.0 \mathrm{~cm}$ thick and had numerous branches and pieces of twigs, roots, and leaves. Several roaches and ants were present among these layers. The involucrum consisted of 7-10 soft, brown layers with a 3.04.0-mm separation between each layer. Brood cells were arranged in five combs separated by pillars, with the newer cells located in the center. Honey pots were located lateral to the brood cells, near the entrance. Each pot was about $13 \mathrm{~mm}$ in length and $11 \mathrm{~mm}$ in width.

The single nest of $P$. moureana was inside a dead E. cyclocarpum tree in a tropical dry forest remnant (Fig. 4). The nest entrance consisted of a small tube (length, $10.0 \mathrm{~mm}$; diameter, $3.0 \mathrm{~mm}$ ) of soft, brownish wax with sinuous margin (Fig. 5) located at $80 \mathrm{~cm}$ above the ground. Workers were very timid and retreated into the nest when disturbed. The nest lacked an involucrum and was about $10.0-\mathrm{cm}$ deep into the wood in a cavity about $6.0 \mathrm{~cm}$ in width and $14.0 \mathrm{~cm}$ in length. Brood cells were in clusters, not in combs, and occupied most of the nest chamber. Newer cells, as indicated by their darker color, were located towards the base of the cavity. Individual worker 

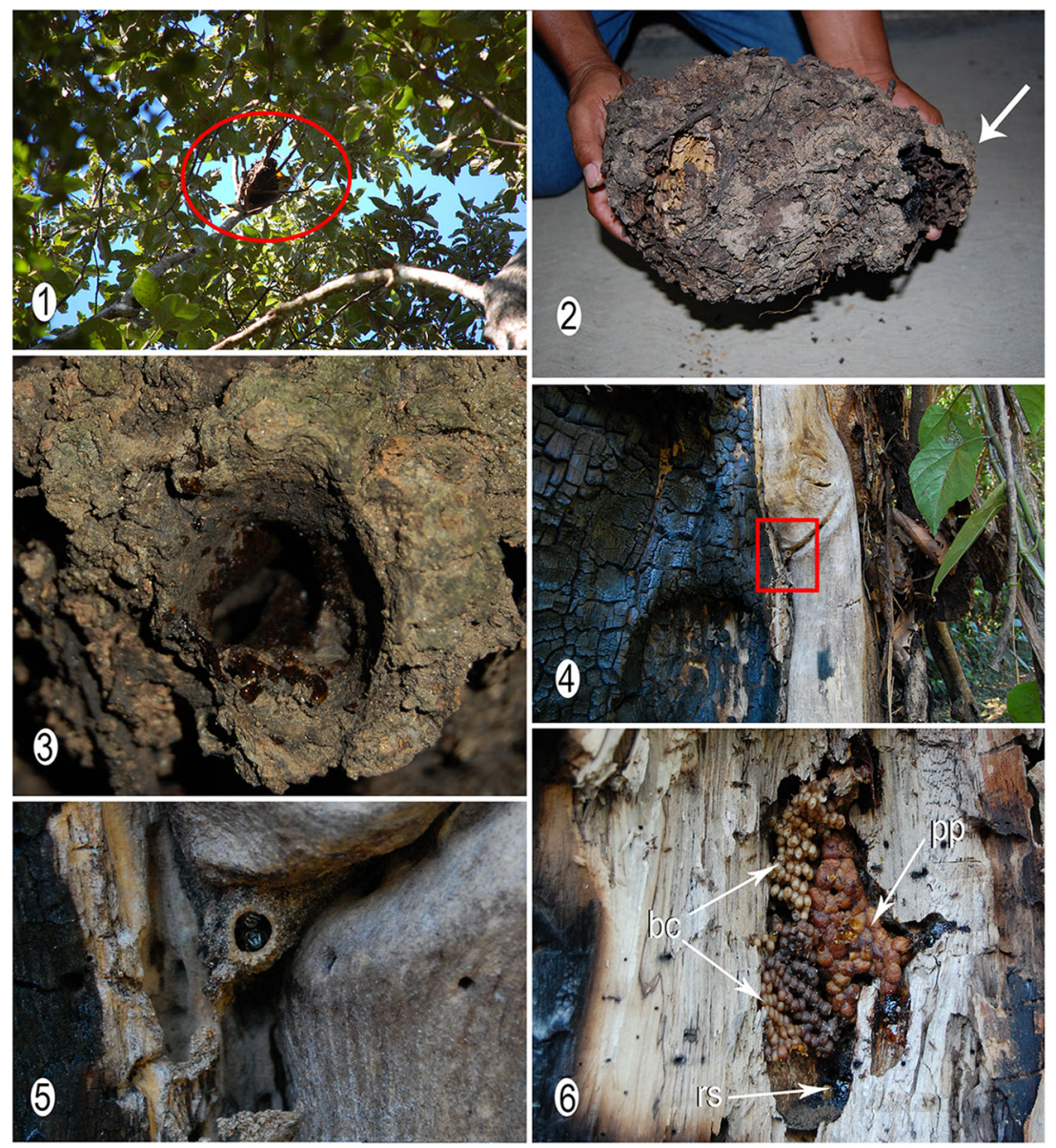

Figs. 1-6. Nests of Partamona bilineata (1-3) and Plebeia moureana (4-6) in Yoloxóchitl, Guerrero, Mexico. 1, aerial nest enclosed by red circle; 2 , nest removed from tree branches with location of entrance indicated by arrow; 3 ,

detail of entrance with dark, sticky resins on its inner walls; 4 , base of dead tree with nest entrance enclosed by red box; 5 , close up of nest entrance; 6 , internal view of nest. bc brood cells, pp pollen pots, rs resin deposits

cells were oval, ranged from 3.7 to $3.8 \mathrm{~mm}$ in length and 2.5 to $2.6 \mathrm{~mm}$ in width, and were oriented slightly perpendicular to the ground. The cluster of pollen pots was about $57.8 \mathrm{~mm}$ in length and 36.7 in width and made of a wax yellower than that of the brood cells (Fig. 6). Pollen pots appeared to be oriented in different directions and each pot was, on average, $8.0 \mathrm{~mm}$ in length and $5.5 \mathrm{~mm}$ in width $(n=10)$. The cluster of honey pots was about $20.8 \mathrm{~mm}$ in length and $16.5 \mathrm{~mm}$ in width and was located on top of the pollen pots. Each pot was, on average, $5.6 \mathrm{~mm}$ in length and $4.6 \mathrm{~mm}$ in width $(n=10)$. The honey was watery and not very sweet. Large

amounts of dark, sticky resin was located at the bottom and top of the nest chamber.

\subsection{Traditional knowledge and uses}

Our consultants demonstrated extensive knowledge of the ecology and natural history of the local stingless bees. They distinguished them based on a combination of the following morphological, sensorial, behavioral, and utilitarian features (see Table S1): body color, size, and smell; defensive, reproductive, and foraging behavior; nest entrance shape and size, nest abundance, shape, location and substrate; and honey taste 
and quantity. On average, each ethnospecies was characterized by $6.4(4-8, \pm 1.51)$ diagnostic features and we did not find significant differences in the number of them used among ethnospecies $\left(X^{2}\right.$ $(5, n=45)=2.1, p=0.91)$.

Consultants referred collectively to stingless bees as $\tilde{n} u^{1} \tilde{n} u^{4}$, a term that also means honey. The honey bee Apis mellifera L. is called $\tilde{n} u^{1} \tilde{n} u^{4}$ $s a{ }^{4} a{ }^{4}$ with the qualifying $s a^{, 4} a n^{4}$ in other contexts referring to "mestizo," i.e., non-native. Each ethnospecies recognized by our consultants corresponded to a currently accepted species concept in bee taxonomy and was distinguished by a second term that referred to a distinctive body or nest feature. Meliponiculture is not practiced in the area. Honey and wax (cerumen) are extracted as needed or whenever nests are found. Honey extraction usually occurs annually between April and May and nests are partially or totally destroyed in the process.

The following paragraphs describe the meaning of the local name, associated uses, and some features of the biology of each ethnospecies, as reported by our consultants. Figures S2A and S2B show some nest structures and main body parts of the adult bee in English and Yoloxóchitl Mixtec.

Frieseomelitta nigra is called $\tilde{n} u^{1} \tilde{n} u^{4} p i^{3} l_{o}{ }^{4}$, which literally means "honey buzzard." The name comes from the distinctive wing color of this species: black with white tips, thus in coloration resembling the wings of the American black vulture, Coragyps atratus (Bechstein). One of the consultants mentioned that when the moon is waning, about 3 days after a new moon, these bees fly about $3 \mathrm{~m}$ away from the nest, hover around it, and then return one by one. This behavior, said to also characterize $S$. hellwegeri and $P$. bilineata, occurs during the day. The honey is bitter-sweet and is not used medicinally. Consultants also mentioned that these bees frequently nest in fence posts, particularly of Leucaena sp. (Fabaceae), and that they gather resins and milky sap from Ficus spp., Sapium glandulosum (L.) Monroy (Euphorbiaceae), and M. indica $\mathrm{L}$.

Nannotrigona perilampoides is called $\tilde{n} u^{1} \tilde{n} u^{4}$ $l i^{3} \mathrm{sa}^{4}$ because its nest entrance resembles an immature ear of corn $\left(l i^{3} s a^{4}\right)$. The honey is used to treat cataracts by applying a drop in the affected eye, and the propolis is sometimes used as a glue (e.g., to attach paper to the sticks of a kite).

The name given to $P$. bilineata, $\tilde{n} u^{1} \tilde{n} u^{4} n d u^{3}$ $c h i^{4}$, refers to the rounded, aerial nest of this species. It literally means "honey/bee bean." Our consultants mentioned that this species builds its nests from squirrel's nests and that they are commonly found in the branches of living mango trees $(M$. indica ). Honey is consumed whenever a nest falls to the ground.

Plebeia moureana was referred as to $\tilde{n} u^{1} \tilde{n} u^{4}$ $l i^{3} m u^{42}$, which means "honey/bee lemon." According to the consultants, the bees smell like lemon when they are squashed. They also mentioned that these bees are attracted to body sweat, particularly when one wears perfume or does not bathe, and they might become an annoyance during hunting because they occasionally get into the eyes. They produce small amounts of honey, which is infrequently consumed or used for any medicinal purposes.

Two names referred to $S$. hellwegeri depending on the body color and type of defensive behavior. $\tilde{N} u^{1} \tilde{n} u^{4} y a^{, 4} a^{1}$, which means "honey coffeecolored" and is given to uniformly browncolored bees that do not defend their nest aggressively, and $\tilde{n} u^{1} \tilde{n} u^{4} m e^{4} k u^{2}$, meaning "honey/bee striped" and applied to bees with banded eyes that aggressively defend their nest. Consultants men-

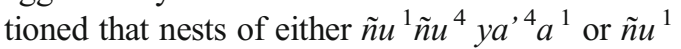
$\tilde{n} u^{4} m e^{4} k u^{2}$ are frequently found in trunks of large trees that are often split and occasionally nesting inside rocks. The preferred trees for this bee species are Quercus spp., Andira inermis (W. Wright) DC. (Fabaceae), and Spondias sp. (Anacardiaceae). This bee produces significant amounts of honey that is used to treat several skin conditions, including cuts and blisters. The honey is applied directly to the affected area and it is said to prevent the formation of a permanent scar. The honey is tasty but when consumed at noon, it makes the person thirsty and might induce vomiting. The wax is used as incense and to treat constipation in infants and colic (corage) in newborns, a cultural disease passed from adults with anger or in pain that is manifested in the infant by a continuous crying. The constipated infant or newborn is placed on a hammock so that it rear end is directly exposed to the resulting fumes from 
burning the wax on charcoal. The wax is also used to seal traditional bowls made of gourds and occasionally by children to glue paper to the sticks of kites. The use of this wax is also captured in oral tradition. One story describes a monkey made of wax used as bait to capture a rabbit that had been eating the plants from a cornfield. This is a local version of the "Br'er Rabbit and the Tarbaby" story from Uncle Remus, common throughout the Americas (Boas 1912; Espinosa 1930; Johnson 1940). The rabbit arrived at night and, curious about the monkey, got stuck in the wax figure while trying to fight it. Bee larvae are often eaten with the honey, but they are not toasted as in the case of paper wasp larvae.

$\tilde{N} u^{1} \tilde{n} u^{4} n u^{3} u^{4}$ is the name given to T. fulviventris because it nests in the ground ( $n u^{\text {, }}$ $u^{4}$ meaning "ground"). According to our consultants, this species nests in abandoned armadillo dens and produces large amounts of honey.

An unidentified ethnospecies, $\tilde{n} u^{1} \tilde{n} u^{4} n a^{, 4}$ $n u^{3}$ (honey/bee big), was mentioned by our consultants. The bees are brown, about as large as honey bees, and are very rare or extinct in the area. Nests are inside branches of oak trees. Bee activity at the nest entrance is minimal because forager bees enter and leave the nest one by one. As in $S$. helleweri, the honey is used to treat skin conditions. The bees were very common in the past and its current absence in the area is attributed to deforestation, as well as to the arrival of Africanized honey bees about 20 years ago.

\subsection{Relative cultural importance}

Our consultants reported nine specific uses for all species of stingless bees recorded during this study (Table II). Based on the relative importance index, $S$. hellwegeri is the most culturally important species in the area followed by $N$. perilampoides. We found a positive relationship between nest abundance and relative cultural importance index, $r_{\mathrm{s}}=0.81, p=0.032$ (Fig. S3).

\section{DISCUSSION}

In general, the nesting biology of stingless bees occurring in Yoloxóchitl agrees with previous observations (e.g., Wille and Michener 1973), except for that of $P$. bilineata. This species is widely distributed in Mexico and Central America, occurring from sea level to $2500 \mathrm{~m}$, and from the state of Sonora to as far south as northern Honduras and El Salvador (Ayala 1999; Camargo and Pedro 2003a). Available data suggest that $P$. bilineata makes subterranean nests in Guatemala (Wheeler 1913) while it makes semi- and fully exposed nests under bridges, ceilings, and outer walls of houses in Veracruz (Rau 1943) and Yucatán, Mexico (GonzálezAcereto 1984). In contrast, all nests observed in this study around Yoloxóchitl were aerial nests located in high branches of living trees (Fig. 2), a behavior consistent with information provided by our consultants. If the species identity of the previously published records is correct, then our results confirm the notion that nest choice in P. bilineata is highly variable. This is not surprising because stingless bees exhibit marked inter- and intraspecific variations in the external nest entrance, internal nest features, and nesting substrate. These are likely the result of constraints imposed by nest site limitations and are often geographically and phylogenetically related (Camargo and Pedro 2003b; Rasmussen and Camargo 2008; Roubik 2006). However, our results also support the suspicion of Ayala (1999) and Camargo and Pedro (2003a), based on some morphological differences (i.e., body size, coloration, and pubescence), on the existence of distinct populations in (1) Guatemala and El Salvador, (2) Yucatán, and (3) the remaining areas of Mexico. Further studies will determine if these populations are actually distinct species

We document for the first time the nesting biology of $P$. moureana, a species endemic to Mexico. Plebeia Schwarz is the most speciesrich genus of stingless bees in Mexico, currently comprising 11 described species and likely several others still undescribed (Ayala et al. 2013). All species of Plebeia are cavity-nesters and most of them arrange their brood cells in combs (Michener 2007). However, a few species, such as P. moureana (Fig. 6), build brood cells in clusters. The latter type of cell arrangement is present in several groups of stingless bees, and it seems to be an adaptive feature of small to minute bees to nest in small, irregular cavities, including underneath tree bark (Michener 2007; Melo and Costa 2009). 
Table II.. Mixtec names, uses, and relative importance value for each species of stingless bees recorded in Yoloxóchitl, Guerrero, Mexico. The unidentified ethnospecies, $\tilde{n} u^{1} \tilde{n} u^{4} n a^{3} n u^{3}$, is also included. It is likely to correspond to Melipona fasciata Latreille given the nesting and behavioral features reported by informants and the species' known distribution. $H$ honey, $L$ larvae, $\# C$ number of categories of use, $\# U$ number of specific uses, $C$ proportion of the total number of categories of use, $U$ proportion of the total number of specific uses, $R C I$ relative cultural importance index $([C+U] \times 50)$. See text for description of each specific use

\begin{tabular}{|c|c|c|c|c|c|c|c|c|c|c|}
\hline \multirow[b]{2}{*}{ Bee species } & \multirow[b]{2}{*}{ Mixtec name } & \multicolumn{4}{|c|}{ Categories of use } & \multicolumn{5}{|c|}{ Relative importance } \\
\hline & & Food & Medicine & Crafts & Other & $\# C$ & $\# U$ & $C$ & $U$ & $\mathrm{RCI}$ \\
\hline $\begin{array}{l}\text { Frieseomelitta } \\
\text { nigra } \\
\text { (Cresson) }\end{array}$ & $\begin{array}{c}\tilde{n} u^{1} \tilde{n} u^{4} \\
p i^{3} l o^{4}\end{array}$ & $\mathrm{H}$ & & & & 1 & 1 & 0.25 & 0.11 & 18.0 \\
\hline $\begin{array}{l}\text { Nannotrigona } \\
\text { perilampoides } \\
\text { (Cresson) }\end{array}$ & $\begin{array}{r}\tilde{n} u^{1} \tilde{n} u^{4} \\
l i^{3} s a^{4}\end{array}$ & $\mathrm{H}$ & Eyes & $\begin{array}{l}\text { Wax } \\
\text { Glue }\end{array}$ & & 3 & 3 & 0.75 & 0.33 & 54.2 \\
\hline $\begin{array}{l}\text { Partamona } \\
\text { bilineata (Say) }\end{array}$ & $\begin{array}{l}\tilde{n} u^{1} \tilde{n} u^{4} \\
n d u^{3} c h i^{4}\end{array}$ & $\mathrm{H}$ & Skin & & & 2 & 2 & 0.50 & 0.22 & 36.1 \\
\hline $\begin{array}{l}\text { Plebeia } \\
\text { moureana } \\
\text { Ayala }\end{array}$ & $\begin{array}{l}\tilde{n} u^{1} \tilde{n} u^{4} \\
\quad l i^{3} m u n^{42}\end{array}$ & $\mathrm{H}$ & & & & 0 & 0 & 0.00 & 0.00 & 0.0 \\
\hline $\begin{array}{l}\text { Scaptotrigona } \\
\text { hellwegeri } \\
\text { (Friese) }\end{array}$ & $\begin{array}{c}\tilde{n} u^{1} \tilde{n} u^{4} \\
y a^{4} a^{1} \\
\tilde{n} u^{1} \tilde{n} u^{4} \\
m e^{4} k u^{2}\end{array}$ & $\begin{array}{l}\mathrm{H} \\
\mathrm{L}\end{array}$ & $\begin{array}{l}\text { Skin } \\
\text { Incense } \\
\text { Constipation } \\
\text { Corage }\end{array}$ & $\begin{array}{l}\text { Wax } \\
\text { Sealing } \\
\text { Glue }\end{array}$ & $\begin{array}{l}\text { Wax- } \\
\text { monkey } \\
\text { in rabbit } \\
\text { story }\end{array}$ & 4 & 9 & 1.00 & 1.00 & 100 \\
\hline $\begin{array}{l}\text { Trigona } \\
\text { fulviventris } \\
\text { Guérin- } \\
\text { Méneville }\end{array}$ & $\begin{array}{c}\tilde{n} u^{1} \tilde{n} u^{4} \\
n u^{3} u^{4}\end{array}$ & $\mathrm{H}$ & & & & 1 & 1 & 0.25 & 0.11 & 18.0 \\
\hline $\begin{array}{l}\text { ?Melipona } \\
\text { fasciata } \\
\text { Latreille }\end{array}$ & $\begin{array}{l}\tilde{n} u^{1} \tilde{n} u^{4} \\
n a^{\prime 4} n u^{3}\end{array}$ & $\mathrm{H}$ & Skin & & & 2 & 2 & 0.50 & 0.22 & 36.1 \\
\hline
\end{tabular}

Similar to what other studies on traditional knowledge of Meliponini have suggested, our consultants distinguished stingless bees based on a number of morphological, behavioral, ecological, and utilitarian features (Costa-Neto 1998; Posey 1993; Posey and Camargo 1985; Zamudio and Hilgert 2012; Reyes-González et al. 2014; Carvalho et al. 2014). At first, we hypothesized that the more abundant species would not only offer greater opportunities for cultural experimentation (and thus create the potential for more varied uses) but that these same species would be more easily recognized through a fewer number of attributed. However, our results suggest that consultants use a similar number of features to identify all species (Table S1). In general, each ethnospecies corresponded to an accepted taxonomic concept in bee systematics, except for $\tilde{n} u^{1} \tilde{n} u^{4} l i^{3} m u^{42}$, which appears to include $L$. chamelensis and P. moureana. The name literally means "honey/bee lemon" because, according to our consultants, bees smell like lemon when they are squashed. Among stingless bees, such a distinctive lemon odor is particularly associated with the cleptobiotic genus Lestrimelitta Friese, which these bees employ during nest raids to deter attacks by adults in their victim colonies (e.g., Sakagami et al. 1993). Lestrimelitta chamelensis is known as "abeja limoncilla" ("lemon bee") in some communities in the contiguous state of Michoacán (Reyes-González et al. 2014). The production of these compounds by the mandibular glands of Plebeia is unknown and bees of $P$. moureana did not smell like lemon when we squashed them. This broad concept for the ethnospecies $\tilde{n} u^{1} \tilde{n} u^{4} l i^{3} m u^{42}$ was surprising because of the unmistakable odor of Lestrimelitta and because our consultants accurately identified 
bees in their ecological niche, such as at their nesting sites. They even made finer distinctions, as in the case of $S$. hellwegeri in which they recognized two "forms" based on their aggressiveness, body color, and odor. To us, these forms are behaviorally and morphologically undistinguishable. Unlike the consultant's ability to identify stingless bees in their ecological niche, they often misidentified bees whenever we presented them in vials or mounted on an insect pin. Similar cases have been reported in other studies (e.g., Posey 1982) and they highlight the reliance and importance of functional classifications in folk taxonomies.

The unidentified species $\tilde{n} u^{1} \tilde{n} u^{4} n a^{, 4} n u^{3}$ is probably Melipona fasciata Latreille based on the description of the nest, body color, habitats, and species distribution. It appears to be locally extinct, which is not surprising given that species of Melipona Illiger are highly sensitive to changes in ecology and landscape (e.g., Brown and Albrecht 2001; Yurrita et al. 2017). Our consultants also mentioned the arrival of Africanized honey bees as another cause of the absence of $\tilde{n} u^{1} \tilde{n} u^{4} n a^{, 4} n u^{3}$ in Yoloxóchitl. Feral honey bees were very common in the area, including the oak forests where $\tilde{n} u^{1} \tilde{n} u^{4}$ $n a^{4} n u^{3}$ used to be found. The buzzing sound produced by the thousands of honey bees foraging on flowers was astonishing during our surveys and we encountered more than 20 wild nests, which is a high number of nests when compared with the 32 nests found for six species of stingless bees in this study.

Unlike some areas of Mexico where meliponiculture is developed (e.g., Yucatán Peninsula; Villanueva-Gutiérrez et al. 2013), the exploitation of stingless bees in the current states of Guerrero and Michoacán, known since preColumbian times, is presently only based on extractive management of wild populations (ReyesGonzález et al. 2014). The number and types of cultural uses reported herein fall within those known for other species of stingless bees in Mexico and from other regions of the world (e.g., Santos and Antonini 2008; Ayala et al. 2013; Villanueva-Gutiérrez et al. 2013; Carvalho et al. 2014; Reyes-González et al. 2014; Vit et al. 2015; Singh 2016; Zamudio and Alvarez 2016). However, it is difficult to assess what reported uses are novel or unique to these bee species in the study area because a comprehensive, comparative, and quantitative analysis of stingless bee uses is not yet available. Likewise, scattered records also preclude us to make quantitative comparisons of the same bee species in other regions. Doubtless, the application of the RCI, as used in this work, might prove useful for future comparative analyses, as it could be based only upon literature review (Hoffman and Gallaher 2007). However, this type of analysis is out of the scope of the present work.

The most versatile species (as per the relative cultural importance index) in Yoloxóchitl was $S$. hellwegeri, an endemic species of Mexico occurring along the Balsas River Basin and along the Pacific Coast, between Oaxaca and Sinaloa (Ayala 1999). Indigenous and non-Indigenous people use this species across its distribution range, including in managed pollination (Ayala et al. 2013; ReyesGonzález et al. 2014). Nannotrigona perilampoides was the second most versatile species and the most commonly encountered in Yoloxóchitl. Our results suggest that the more abundant species of stingless bees are more versatile than less abundant species, a pattern widely described in ethnobotany. This is known as the "apparency hypothesis," which states that people have more opportunities to experiment and attribute uses to most abundant plants because they are more frequently found. Once uses are discovered and learned, subsequent frequency of use will depend on local availability (e.g., Phillips and Gentry 1993b). It would be interesting to test this apparency hypothesis in areas with a greater diversity of stingless bees.

Finally, our study demostrates the value of incorporating traditional knowledge in bee surveys. First, they might facilitate a rapid assessment of the local richness of the bee fauna. Second, they might provide additional biological or ecological information not available to scientists during initial surveys without the input of local peoples. Third, they can rapidly enrich species concepts by adding a plethora of cultural information gathered by the people who have been living in close proximity to stingless bees for centuries. Our consultants knew with great precision the nesting sites, trees, and habitats preferred by the bees and quickly found their nests. They were also aware of the recent disappearance of one species. We hope this work encourages future ethnomelittological studies. 


\section{ACKNOWLEDGEMENTS}

We thank Ricardo Ayala for discussions on bee species identities and Esteban Castillo García, Rey Castillo García, Esteban Guadalupe Sierra, and Constantino Teodoro Bautista for their generosity in sharing their knowledge of the local fauna. We are grateful to Amy Comfort and two anonymous reviewers for comments and suggestions that improved this manuscript.

\section{AUTHORS CONTRIBUTION}

VHG, JDA, and TJS conceived and performed experiments, analyzed the data, and wrote the paper. All the authors have read and approved the submitted manuscript.

\section{FUNDING INFORMATION}

This work was supported by the National Science Foundation, Documenting Endangered Languages award \#0966462 (J. Amith, PI) and the Endangered Language Documentation Programme (School of Oriental and African Studies, London) grant MDP0201 (J. Amith, PI). Partial support to V.H.G. and T.J.S. was received through a NSF's REU program (DBI 1560389) and the Department of Biological Sciences, Southwestern Oklahoma State University, Weatherford, Oklahoma.

\section{OPEN ACCESS}

This article is distributed under the terms of the Creative Commons Attribution 4.0 International License (http://creativecommons.org/licenses/by/4.0/), which permits unrestricted use, distribution, and reproduction in any medium, provided you give appropriate credit to the original author(s) and the source, provide a link to the Creative Commons license, and indicate if changes were made.

L'écologie de la nidification et l'importance culturelle des abeilles sans dard des personnes de langue maternelle Yoloxóchitl Mixtec, une langue menacée à Guerrero, Mexique

conservation / indice d'importance culturelle / ethnomelittologie / meliponiculture / architecture de nid
Nestökologie und kulturelle Bedeutung von Stachellosen Bienen für Muttersprachler von Yoloxóchitl Mixtec, einer stark bedrohten Sprache in Guerrero, Mexico

erhaltung / kultureller bedeutungsindex / ethnomelittologie / meliponinenkultur / nestarchitektur

\section{REFERENCES}

Ayala, R. (1999) Revisión de las abejas sin aguijón de México (Hymenoptera: Apidae: Meliponini). Folia Entomol. Mex. 106, 1-123

Ayala, R., Gonzalez, V.H., Engel, M.S. (2013) Mexican stingless bees (Hymenoptera: Apidae): diversity, distribution and indigenous knowledge, in: Vit, P., Pedro, S.R.M. and Roubik, D.W. (Eds.), Pot-honey: a legacy of stingless bees. Springer, New York, USA, pp. 135-152

Bennett, B.C., Prance, G.T. (2000) Introduced plants in the indigenous pharmacopoeia of northern South America. Econ. Bot. 54(1), 90-102

Berenbaum, M.R., Bernhardt, P., Buchmann, S., Calderone, N.W., Goldstein, P., Inouye, D.W., Kevan, P., Kremen, C., Medellin, R., Ricketts, T.H., Robinson, G.E., Snow, A.A., Swinton, S., Thien, L.B., Thompson, F.C. (2006) Status of Pollinators in North America. National Academies Press, Washington, D.C. (http://www.nap.edu).

Biesmeijer, J.C., Roberts, S.P.M., Reemer, M., Ohlemüller, R., Edwards, M., Peeters, T., Schaffers, A.P., Potts, S.G., Kleukers, R., Thomas, C.D., Settele, J., Kunin, W.E. (2006) Parallel declines in pollinators and insectpollinated plants in Britain and the Netherlands. Science $\mathbf{3 1 3}, 351-354$

Boas, F. (1912) Notes on Mexican folk-lore. J. Am. Folk. 25 (97), 204-260

Brown, C., Albrecht, C. (2001) The effect of tropical deforestation on stingless bees of the genus Melipona (Insecta: Hymenoptera: Apidae: Meliponini) in central Rondonia, Brazil. J. of Biogeogr. 28 (5), 623-634

Camargo, J.M.F., Pedro, S.R.M. (2003a) Meliponini neotropicais: o gênero Partamona Schwarz, 1939 (Hymenoptera, Apidae). Rev. Bras. Entomol. 47 (Supl. 1), $1-117$

Camargo, J.M.F., Pedro, S.R.M. (2003b) Meliponini neotropicais: o gênero Partamona Schwarz, 1939 (Hymenoptera, Apidae, Apinae) - bionomia e biogeografia. Rev. Bras. Entomol. 47 (3), 311-372

Camargo, J.M.F., Pedro, S.R.M. (2007) Meliponini Lepeletier, 1836, in: Moure, J.S., Urban, D. and Melo, G.A.R. (Eds.), Catalogue of bees (Hymenoptera, Apoidea) in the neotropical region. Sociedade Brasileira de Entomologia, Curitiba, Brazil, pp. 272578 Available and updated online at http://www. moure.cria.org.br/catalogue (accessed on 20 January 2017)

Carvalho, R.M.A., Martins, C.F., Mourão, J.S. (2014) Meliponiculture in Quilombola communities of 
Ipiranga and Gurugi, Paraíba state, Brazil: an ethnoecological approach. J. Ethnobiol. Ethnomed. 10, 3, DOI: https://doi.org/10.1186/1746-4269-10-3

Castillo, G.R. (2007) Descripción fonológica, segmental, y tonal del Mixteco de Yoloxóchitl, Guerrero (Master's thesis). Centro de Investigaciones y Estudios Superiores en Antropología Social (CIESAS), México, D.F.

Costa-Neto, E.M. (1998) Folk taxonomy and cultural significance of "abeia" (Insecta, Hymenoptera) to the Pankararé, northeastern Bahia state, Brazil. J. Ethnobiol. 18(1), 1-13

DiCanio, C., Nam, H., Amith, J.D., Castillo, G.R., Whalen, D.H. (2015) Vowel variability in elicited versus spontaneous speech: evidence from Mixtec. J. Phonetics 48, 45-59

Espinosa, A. M. (1930) Notes on the origin and history of the tar-baby story. J. Am. Folk. 43 (168), 129-209

González-Acereto, J. A. (1984) Acerca de la regionalización de la nomenclatura Maya de las abejas sin aguijón (Melipona sp) en Yucatán. Rev. Geogr. Agric. 5-6, 190-193

Gonzalez, V.H., Griswold, T., Engel, M.S. (2013) Obtaining a better taxonomic understanding of native bees: where do we start? Syst. Entomol. 38 , 645-653

Hoffman, B., Gallaher, T. (2007) Importance indices in ethnobotany. E. R. A. 5, 201-218

IPBES (2016) Summary for policymakers of the assessment report of the Intergovernmental Science-Policy Platform on Biodiversity and Ecosystem Services on pollinators, pollination and food production. Potts, S. G., Imperatriz-Fonseca, V. L., Ngo, H. T., Biesmeijer, J. C., Breeze, T. D., Dicks, L.V., Garibaldi, L. A., Hill, R., Settele, J., Vanbergen, A. J., Aizen, M. A., Cunningham, S. A., Eardley, C., Freitas, B. M., Gallai, N., Kevan, P. G., Kovács-Hostyánszki, A., Kwapong, P. K., Li, J., Li, X., Martins, D. J., Nates-Parra, G., Pettis, J. S., Rader, R., and Viana, B. F. (Eds.). Secretariat of the Intergovernmental Science-Policy Platform on Biodiversity and Ecosystem Services, Bonn, Germany. $36 \mathrm{pp}$

Johnson, J. B. (1940) Three Mexican tar baby stories. J. Am. Folk. 53 (208/209), 215-217

Klein, M.A., Vaissière, B.E., Cane, J.H., Steffan-Dewenter, I., Cunningham, S.A., Kremen, C., Tscharntke, T. (2007) Importance of pollinators in changing landscapes for world crops. Proc. R. Soc. Lond. B. Biol. Sci. 274, 303-313

Melo, G.A.R., Costa, M.A. (2009) A new cluster-brood building species of Plebeia (Hymenoptera, Apidae) from eastern Brazil. Rev. Bras. Entomol. 53 (1), 77-81

Michener, C.D. (1959) Sibling species of Trigona from Angola (Hymenoptera, Apinae). Am. Mus. Novit. 1956, 1-5

Michener, C.D. (2007) The Bees of the World, 2nd edn. Johns Hopkins University Press, Baltimore, USA.

Phillips, O. (1996) Some quantitative methods for analyzing ethnobotanical knowledge, in: Alexiades, M. and Sheldon, J.W. (Eds.), Selected guidelines for ethnobotanical research: a field manual. New York Botanical Garden Press, Bronx, New York, USA, pp. 171-197

Phillips, O., Gentry, A.H. (1993a) The useful plants of Tambopata, Peru: I. Statistical hypotheses tests with a new quantitative technique. Econ. Bot. 47 (1), 15-32

Phillips, O., Gentry, A.H. (1993b) The useful plants of Tambopata, Peru: II. Additional hypothesis testing in quantitative ethnobotany. Econ. Bot. 47 (1), 33-43

Portugal-Araújo, V., Kerr, W.E. (1959) A case of sibling species among social bees. Rev. Bras. Biol. 19(3), 223-228

Posey, D.A. (1982) The importance of bees to Kayapó Indians of the Brazilian Amazon. Fla. Entomol. 65(4), 452-458

Posey, D.A. (1983) Keeping of stingless bees by the Kayapo' Indians of Brazil. J. Ethnobiol. 3 (1), 63-73

Posey, D.A. (1993) Indigenous knowledge in the conservation and use of world forests, in: Ramikrishna, K. and Woodwell, G. (Eds.), World forest for the future: their use and conservation. Yale University Press, New Haven, Connecticut, USA, pp. 59-77

Posey, D.A., Camargo, J.M.F. (1985) Additional notes on the classification and knowledge of stingless bees (Meliponinae, Apidae, Hymenoptera) by the Kayapó Indians of Gorotire, Pará, Brazil. Ann. Carnegie Mus. 54 (8), 247-274

Potts, S.G., Biesmeijer, J.C., Kremen, C., Neumann, P. Schweiger, O., Kunin, W.E. (2010) Global pollinator declines: trends, impacts and drivers. Trends Ecol. Evolut. 25, 345-353

Potts, S.G., Imperatriz-Fonseca, V., Ngo, H.T., Aizen, M.A., Biesmeijer, J.C., Breeze, T.D., Dicks, L.V., Garibaldi, L.A., Hill, R., Settele, J., Vanbergen, A.J. (2016) Safeguarding pollinators and their values to human well-being. Nature DOI: https://doi.org/10.1038 /nature20588

Rasmussen, C., Camargo, J.M.F. (2008) A molecular phylogeny and the evolution of nest architecture and behavior in Trigona s.s. (Hymenoptera: Apidae: Meliponini). Apidologie 39(1), 102-118

Rau, P. (1943) Notes on the nesting habits of certain social and solitary bees of Mexico. Ann. Entomol. Soc. Am. 36 (4), 641-646

Reyes-González A., Camou-Guerrero A., Reyes-Salas O., Argueta A., Casas, A. (2014) Diversity, local knowledge and use of stingless bees (Apidae: Meliponini) in the municipality of Nocupétaro, Michoacan, Mexico. J. Ethnobiol. Ethnomed. 10, 47, DOI: https://doi. org/10.1186/1746-4269-10-47

Roubik, D.W. (2006) Stingless bee nesting biology. Apidologie 37 (2), 124-143

Sakagami, S.F., Roubik, D.W., Zucchi R. (1993) Ethology of the robber stingless bee, Lestrimelitta limao. Sociobiology 21 (2), 237-277

Santos, G.M., Antonini, Y. (2008) The traditional knowledge on stingless bees (Apidae: Meliponina) used by the Enawene-Nawe tribe in western Brazil. J. 
Ethnobiol. Ethnomed. 10, 47, DOI: https://doi. org/10.1186/1746-4269-4-19

Schwarz, H.F. (1948) Stingless bees (Meliponidae) of the Western Hemisphere, Bull. Am. Mus. Nat. Hist. 90, 1546

Singh, A.K. (2016). Traditional meliponiculture by Naga tribes in Nagaland, India. IJTK 15, 693-699

Slaa, E.J., Sánchez, L.A., Malagodi-Braga, K.S., Hofstede, F.E. (2006) Stingless bees in applied pollination: Practice and perspectives. Apidologie 37 (2), 293-315

Stearman, A.M., Stierlin, E., Sigman, M.E., Roubik, D.W., Dorrien, D. (2008) Stradivarius in the jungle: traditional knowledge and the use of "black beeswax" among the Yuquí of the Bolivian Amazon. Hum. Ecol. 36 (2), 149-159

Villanueva-Gutiérrez, R., Roubik, D.W., Colli-Ucán, W., Güemez-Ricalde, F.J., Buchmann, S.L. (2013) A critical review of colony losses in managed Mayan honeymaking bees (Apidae: Meliponini) in the heart of Zona Maya. J. Kansas Entomol. Soc. 86 (4), 352-362

Vit, P., Vargas, O., López, T., Maza, F. (2015) Meliponini biodiversity and medicinal uses of pot-honey from El Oro province in Ecuador. E. J. F. A. 27 (6), 502-506
Wheeler, W.M. (1913) Notes on the habits of some Central American stingless bees. Psyche 20 (1), 1-9

Wille, A., Michener, C.D. (1973) The nest architecture of stingless bees with special reference to those of Costa Rica (Hymenoptera: Apidae), Rev. Biol. Trop. Suppl. 21, 9-278

Yurrita, C.L., Ortega-Huerta, M.A., Ayala, R. (2017) Distributional analysis of Melipona stingless bees (Apidae: Meliponini) in Central America and Mexico: setting baseline information for their conservation. Apidologie. 48, 247-258

Zamudio, F., Alvarez, L.J. (2016) Abejas sin Aguijón de Misiones. Una guía etnotaxonómica para su identificación en el campo. Editorial de la Universidad Nacional de Córdoba, Argentina.

Zamudio, F., Hilgert, N.I. (2012) Descriptive attributes used in the characterization of stingless bees (Apidae: Meliponini) in rural populations of the Atlantic forest (Misiones-Argentina). J. Ethnobiol. Ethnomed. 8, 9, DOI: https://doi.org/10.1186 /1746-4269-8-9 